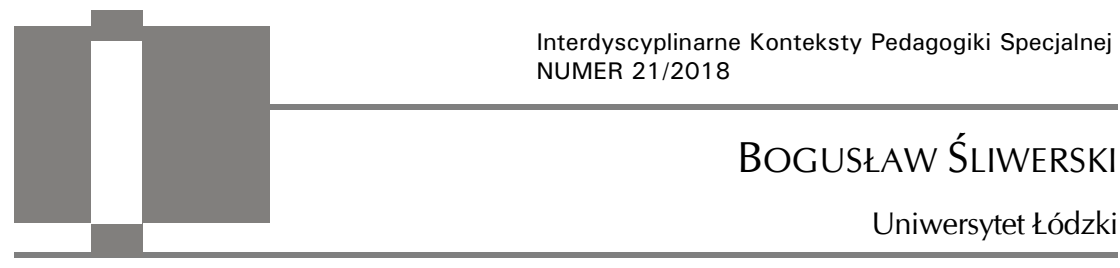

\title{
Wyjątkowość fenomenu harcerskiego wychowania
}

\begin{abstract}
Bogusław Śliwerski, Wyjątkowość fenomenu harcerskiego wychowania [The uniqueness of the phenomenon of the scouting-based education]. Interdyscyplinarne Konteksty Pedagogiki Specjalnej, nr 21, Poznań 2018. Pp. 13-30. Adam Mickiewicz University Press. ISSN 2300-391X. DOI: https:// doi.org/10.14746/ikps.2018.21.02

The world scout movement, including the Polish scout movement refers to a lesser or even to an orthodox extent to the pedagogical ideas and assumptions of Scouting by Robert Stephenson Baden-Powell and the successors of his pedagogics. In the article I respond to the question, to what extent does contemporary pedagogical thought refer to the phenomenon of scout movement education? Can we speak of the pedagogy of scouting or rather of scouting pedagogics? These issues cannot be solved solely on the level of normative models if one would not reach to former studies without indicating the necessity of conducting a scientific turn in this regard.
\end{abstract}

KEY WORDS: scouting, scout movement, education, pedagogics, scouting pedagogy, pedagogics of scouting

Praktykowanie harcerstwa jest bardzo szerokie. Także w środowiskach pedagogicznych. Rozważania o harcerstwie, teoria harcerstwa, w Polsce prawie nie istnieje 1.

${ }^{1}$ A. Kamiński, Przedmowa [w:] Skauting i Harcerstwo. Wybór pism charakteryzujacych ruch młodzieży i system wychowawczy, oprac. Aleksander Kamiński, Oficyna Wydawnicza „Impuls”, Kraków 2015, s. 5 (Reprint maszynopisu autorskiego z 1946 roku). 


\section{Wstęp}

Kwestia wychowania w skautingu, który $\mathrm{w}$ swoich polskich dziejach przyjął własną nazwę - harcerstwo, wymaga usytuowania $\mathrm{w}$ pedagogice harcerskiej, która w XXI w. musi być osadzona w dziedzinie nauk humanistycznych i społecznych. Istnieje już bogata literatura przedmiotu badań tego ruchu oraz źródeł jego ewoluowania w toku dziejów, ze szczególnym ich rozwinięciem w odniesieniu do lat transformacji ustrojowej Rzeczypospolitej od $1989 \mathrm{r}$. Miejscami, ze względu na przywoływane źródła, pisząc o skautingu, będę odnosił swoje analizy do harcerstwa niezależnie od tego, czy mamy na uwadze Związek Harcerstwa Polskiego, Związek Harcerzy Rzeczypospolitej, czy inną organizację harcerską w naszym kraju. Nawiązuję do socjologicznej przesłanki Floriana Znanieckiego, który w swoim studium z socjologii wychowania stwierdza krzyżowanie się w społeczeństwach różnych grup społecznych, przy czym pomimo cechującej je wielości, różnorodności i odrębności są takie, które ogniskują swoje działania wokół wpływowej grupy, jaką dla mnie jest $w$ tym przypadku właśnie skauting. W ujęciu socjologa:

wpływ krzyżujących się grup w stosunku podporządkowania nie zawsze jest jednostronny, że słabsza i mniej liczna grupa, pod pewnymi względami podporządkowana grupie licznej i potężnej, sama również przez swych członków stara się, często z powodzeniem, na nią wpłynąc $\mathrm{i}$ w pewnych innych sprawach sobie ja podporządkować ${ }^{2}$.

Każde harcerstwo w Polsce w mniejszym lub nawet ortodoksyjnym zakresie odwołuje się do idei i założeń pedagogicznych skautingu Roberta Stephensona Baden-Powella oraz kontynuatorów jego pedagogii. $W$ tym sensie każde harcerstwo jest $w$ jakimś stopniu od nich zależne, nasycając pedagogię harcerską czynnikami ją częściowo różnicującymi w stosunku do innych harcerstw.

2 F. Znaniecki, Socjologia Wychowania, tom I. Wychowujące społeczeństwo, Książnica - Atlas Towarzystwo Nauczycieli Szkół Wyższszych, Warszawa 1928, s. 49. 
Warto nadmienić, że w większości krajów są zupełnie oddzielne organizacje skautowe żeńskie i męskie, często osobne katolickie, protestanckie, YMCA i nawet partyjne. Chlubą naszą jest, że pomimo wielu przeciwności, potrafiliśmy jednak utrzymać jedność3 3 .

Po kilkudziesięciu latach niewoli i zniewolenia w czasach nazistowskiej, a następnie radzieckiej przemocy fizycznej, strukturalnej i symbolicznej, po zlikwidowaniu cenzury politycznej nareszcie możemy publikować studia monograficzne i wyniki badań podstawowych o środowisku socjalizacyjnym i wychowawczym, którego fundamentalne założenia aksjonormatywne, metodyka pracy z osobami trzech generacji - dzieci, dorosłych i osób starszych oraz odroczone w czasie osiągnięcia mogą sprzyjać ich dalszej realizacji w adekwatnych do zmieniającej się rzeczywistości warunkach społecznych, gospodarczych, politycznych i osobistych.

\section{Pedagogika a pedagogia harcerska}

To, że harcerstwo ma w swoich założeniach przede wszystkim funkcję socjalizacyjną, a więc pośredniego wychowania i wychowawczą, było przedmiotem wielu rozpraw naukowych w okresie II Rzeczypospolitej, które zostały wyłączone przez kilkadziesiąt lat z powszechnego dostępu do ich treści aż do 1990 r., kiedy to została zniesiona w Polsce cenzura. Nie stały się zatem podstawą do zaktualizowania zawartych $\mathrm{w}$ nich przesłanek i argumentacji ${ }^{4}$. Warto powrócić do tezy historyka Adama Massalskiego:

${ }^{3}$ J. Tworkowska, Równajmy krok. O wspótpracy z Ruchem Harcerskim Nauczycielstwa i Rodziców, Oficyna Wydawnicza „Impuls”, Kraków 2016 (reprint wydania z 1931 roku), s. 36.

4 W latach 2014-2017 ukazało się w Oficynie Wydawniczej „Impuls” pod redakcją Wojciecha Śliwerskiego 141 reprintów publikacji z lat 1909-1939, które przez łączny okres prawie 80 lat były niedostępne polskiej nauce, środowiskom harcerskim i instruktorskim w wyniku okupacji, cenzury i rozproszenia źródeł. 
że harcerstwo polskie to skauting plus niepodległość i myśl pedagogiczna. Myśl pedagogiczna, której poziom wyróżnia harcerstwo wśród innych organizacji skautowych ${ }^{5}$.

W pokonferencyjnym tomie, w którym ów kielecki uczony opublikował swój list do uczestników naukowej debaty, jest artykuł Kazimierza B. Schütterly, w którym przyznaje on, że pedagogika harcerska nie została uznana za wyodrębnioną dyscyplinę naukową. Stało się tak pomimo realizowanego do 1989 r. w szkolnictwie wyższym przedmiotu „Metodyka wychowania w ZHP”. „We wczesnych latach 90. pedagogika harcerska była dyscypliną postulowaną. Mówiono o niej jako o przedmiocie" 6 . Po 1990 r. przedmiot ten jednak został wycofany $\mathrm{z}$ programów kształcenia pedagogicznego, natomiast jeszcze ukazywały się nieliczne opracowania o charakterze metodycznym mające wskazywać - zdaniem tego autora - na jednak istnienie takiej pedagogiki.

Najsilniej zaciążyły na wymiarze samowychowawczym harcerstwa idee krzewione przez towarzystwo „Eleusis”, w którym działali najwybitniejsi twórcy polskiego skautingu, jego inicjatorzy, jak: Andrzej Małkowski, Jerzy Grodyński, Ignacy Kozielewski, Tadeusz Strumiłło czy twórczyni rodzimego skautingu żeńskiego Olga Drahonowska-Małkowska. Dzięki nim, ich niewątpliwym wpływom na cały ruch, pogłębiony został harcerski ideał wychowawczy o pierwiastki narodowe poprzez nawiązanie do eleuzyńskiej idei braterstwa, ascezy, ekumenicznego wymiaru diakoni, karności i lojalności oraz perfekcjonizmu, harmonijnego rozwoju osobowości. Reguła ta ulegała różnym przekształceniom, uzyskując w obecnym wydaniu z 2017 r. treść znacząco od niej odchodzącą - „Harcerz pracuje nad sobą, jest czysty w myśli, mowie i uczynkach; jest wolny od nało-

${ }^{5}$ A. Massalski, Przewodniczacy Zwiazku Harcerstwa Polskiego, [w:] Dorobek pedagogiki harcerskiej. Materiaty z konferencji naukowej zorganizowanej w 50. rocznice powstania "Nieprzetartego Szlaku”, Wyższa Szkoła Filozoficzno-Pedagogiczna „Ignatianum”, Komisja Historyczna Krakowskiej Chorągwi ZHP, Kraków 2008, s. 9.

${ }^{6}$ K. B. Schütterly, Pedagogika ZHP - mity a rzeczywistość, [w:] Dorobek pedagogiki..., op. cit., s. 105. 
gów"7. Adaptowany angielski skauting w sferze ideologicznej był z jednej strony pogłębiany, nasycany narodowym pierwiastkiem, z drugiej zaś, w przesadnej obawie o zarzucanie współczesnemu harcerstwu związku z doktryną burżuazyjnego wychowania, był on "spłycany" czy pozbawiany całkowicie pożądanych z wychowawczego punktu widzenia walorów o uniwersalnym, pozaideologicznym charakterze. Zachowała się jednakże idea ujmowania ruchu harcerskiego jako ruchu samowychowawczego, który premiuje w swoich metodach samodzielność, inicjatywę, twórczość, zaradność i sprawność psychofizyczną. Współczesne harcerstwo nie ustrzegło się jednak niebezpieczeństwa, które R. Baden Powell określał mianem „przefilozofowania skautingu, robienia z niczego rzeczy bardzo mądrej, teorji naukowej"8. Obradujący w Genewie w 1922 r. uczestnicy Trzeciego Kongresu Wychowania Moralnego uznali skauting za „najwybitniejszy czyn pedagogiczny naszej epoki”9.

Mamy za sobą próbę wpisania w okresie PRL-u teoretycznej wiedzy praktycznej i teoretycznej (w tym także historycznej) o harcerstwie w zakres nauk o wychowaniu, wyłaniając w nich m.in. pedagogikę harcerską, co jednak się nie przyjęło. Nie ma zatem pedagogiki harcerskiej, ale jest pedagogia tego środowiska, czyli uniwersalna sztuka (częściowo metoda) inkulturacji, wspomagania indywidualnego rozwoju i uspołecznienia dzieci i młodzieży w harcerstwie jako wyjątkowym - ze względu na jego specyficzne cechy - środowisku socjalizacyjnym. Podobnie jak ma to miejsce w systemie oświatowym, możemy mówić o zgromadzonej w toku stulecia istnienia i rozwoju tego ruchu usystematyzowanym, teoretycznym uzasadnieniu i wyposażeniu w bogatą aparaturę pojęcio-

${ }^{7}$ Harcerz jest wolny od natogów - 10 punkt Prawa Harcerskiego zmieniony, https:/ / zhp.pl/2017/harcerz-jest-wolny-od-nalogow-10-punkt-prawa-harcerskiego-zmienio ny/ [dostęp: 10.01.2018].

${ }^{8} \mathrm{H}$. Glass, Gawędy z drużynowym. Zbiór rad i wskazówek dla instruktorów harcerskich, Warszawa 1923, s. 48.

${ }^{9}$ Za: T. Strumiłło, Harcerstwo a szkoła, [bez miejsca wydania i daty/nadbitka] W. Błażejewski, Bibliografia Harcerska 1911-1960, Warszawa 1980, s. 163. sugeruje rok wydania 1921. 
wą założeń i twierdzeń dotyczących wychowywania człowieka, odniesionym do składników rozumienia tego pojęcia. Harcerstwo jest doktryną pedagogiczną, jeśli stwierdzamy, że ma ono swoją odrębną wiedzę na temat tego, jak należy pojmować w nim wychowanie (harcerskie), czym ono jest, jakie jest jego znaczenie, co jest jego specyfiką i jakie ma cechy.

W toku ewolucji tego ruchu ów fenomen nie zatracił swoich fundamentalnych wyznaczników. Harcerstwo stanowi to wszystko, czego ludzie uczą się w nim poza oficjalnie dostępnym i znanym programem Związku. Tym samym harcerstwo jest tym wszystkim, czego uczy sam fakt przebywania w nim jako środowisku socjalizacyjno-wychowawczym, a co nie było jego funkcją założoną. Pluralizm ruchu harcerskiego wynika $\mathrm{z}$ istniejących wśród jego kadr różnic w zakresie doktryny pedagogicznej i ideologii wychowawczej. Natomiast każda z jego odmian dotknięta jest ukrytym program wychowawczym. Przekonywanie zatem, że któreś z harcerstw jest lepsze, bardziej wartościowe czy politycznie poprawne nie zabezpiecza przed tym, do czego nie chciałoby doprowadzać, a mimo to sprzyja możliwemu np. osobistemu rozczarowaniu, słabej rekrutacji, pozoranctwu, blagierstwu, nudzie czy bylejakości. Natomiast każda z jego odmian dotknięta jest ukrytym programem wychowawczym.

Jak pisał w 1946 r. Józef Sosnowski:

Bliskoznaczny wyraz „pedagogia” - oznacza właśnie sztukę wychowania. [...] ktoś wiedziony tzw. intuicją, bez znajomości pedagogiki, uprawiając zatem pedagogię, może skutecznie wychowywać. Pedagogię uprawia zapewne większość matek w stosunku do swoich dzieci10.

Współcześnie pojęcie pedagogii ma kilka znaczeń: 1) jest sztuką skutecznego wywierania wpływu na dzieci i młodzież dla zrealizowania określonych celów edukacyjnych, metaforycznie rzecz ujmując: „uprawą ludzkiego ducha”; 2) rodzajem doktryny peda-

${ }^{10} \mathrm{~J}$. Sosnowski, O wychowaniu w ogóle i wychowaniu harcerskim, Oficyna Wydawnicza „Impuls”, Kraków 2016 (Reprint z nieopubl. wydruku z 1946 roku), s. 11. 
gogicznej, ideologii edukacyjnej lub ukrytego programu wychowania; 3) w obszarze anglojęzycznym - jest względnie spójnym i trwałym zbiorem praktyk edukacyjnych, poprzez które jednostka przyswaja sobie nowe (lub rozwija dotychczas istniejące) formy postępowania, wiedzy, umiejętności i kryteria ich oceny, przejmując je od kogoś (lub czegoś), kogo uznaje za stosownego ich dostarczyciela (przekaziciela) i ewaluatora11. Pedagogia jest zatem społeczną praktyką wychowawczą, mającą swoje uzasadnienie w refleksji, doświadczeniu biograficznym, a więc wiedzy potocznej, ale także częściowo naukowej. Pedagogika natomiast jest terminem zarezerwowanym w nauce do określenia za jego pośrednictwem odrębności dyscypliny naukowej (lub dziedziny wiedzy) o procesach edukacyjnych, której zadaniem jest wytwarzanie wiedzy o całokształcie praktyki oraz teorii edukacyjnej - minionej i aktualnej. „Obiektem badań tak rozumianej pedagogiki są więc pedagogie we wszystkich swoich znaczeniach"12.

Harcerstwo jako pedagogia jest zarówno doktryną pedagogiczną, ideologią pedagogiczną, jak i ukrytym - w pozytywnym tego słowa znaczeniu - konceptem samowychowania wszystkich jego członków: dzieci, młodzieży, dorosłych i osób starszych. Stanisław Sedlaczek pisał o pracach Baden-Powella, że:

mają charakter pedagogiczny i publicystyczny. Stąd zasadnicza trudność zupełnie ścisłego ustalenia, co jest wyrazem istotnym poglądów B.P., a co spowodowane w mniejszym lub większym stopniu taktyką wychowawczą. Mniemam, że można założyć, iż B.P. celom pedagogicznym jednak poglądów swoich zasadniczych nie podporządkowywał, że wobec tego wypowiedzenia się jego w kwestjach zasadniczych można uważać za istotny, prawdziwy wyraz poglądów ${ }^{13}$.

Harcerstwo jako pedagogia nie musi zmierzać ku akademickiej pedagogizacji swoich kadr, a więc wpisywania, wyjaśniania i inter-

11 T. Hejnicka-Bezwińska, Pedagogika ogólna, WAiP, Warszawa 2008, s. 493.

12 Ibidem, s. 495.

13 S. Sedlaczek, Podstawy etyczne skautingu Baden-Powellowskiego, Oficyna Wydawnicza „Impuls”, Kraków 2015, s. 6. (Reprint wydania z 1928 roku). 
pretowania zachodzących w tym ruchu procesów w taki sam sposób, jak czyni to pedagogika współczesna w edukowaniu przyszłych pedagogów, gdyż może czerpać z zasobów, nie siląc się na własną, jakąś naukową autonomię. Wystarczy, że nauki pedagogiczne wystarczająco silnie reagują na najnowsze nurty myśli teoretycznej w humanistyce i w naukach społecznych, a także $w$ innych dziedzinach życia, by dzięki wzbogacaniu procesu kształcenia kadr instruktorskich o chociaż część tej wiedzy, móc zbliżać się do lepszego rozumienia i wyjaśniania procesów, na które można mieć większy wpływ bądź też dysponować większą świadomością ich wpływu. Wyjątkowość pedagogiki jako nauki dla harcerskiej pedagogii polega na tym, że pytając o wzorce krytyczności i ich ukryte założenia, umożliwia formułowanie pytania o jego własną tożsamość. Odsłania wielorakość i ambiwalencję m.in. dobra i zła, prawdy i fałszu, piękna i kiczu, nadziei i porażek, życia i śmierci, chaosu i porządku, przymusu i wolności, wpływu i oporu, tradycji i przeszłości, odpowiedzialności i nieodpowiedzialności w kształceniu i wychowaniu, pozwalając zarazem na odczytanie poprzez te kategorie losów autentyczności tych procesów, na dostrzeganie ich dynamiki i realnych zagrożeń, napięć, sytuacji i procesów. Dzięki rozpoznaniu układu biegunowych dynamizmów pedagogika uwypukla i respektuje zarazem wagę przeciwstawnych sobie zjawisk, uczulając na podwojenie kryjących się w tym napięciu niebezpieczeństw, ograniczeń czy zagrożeń, akcentując dramatyczne rozdarcie i niepokój.

Instruktorzy harcerscy, choć nie muszą, a w większości i zapewne nie są nauczycielami czy profesjonalistami w szeroko rozumianej dziedzinie edukacji, to jednak $\mathrm{z}$ racji pełnionych, a ustrukturyzowanych także instytucjonalnie ról, stają się lub już są pedagogami. Aleksander Kamiński wyróżniał dwa typy pedagogów: profesjonalistów i amatorów. Wśród tych pierwszych tylko ci nauczyciele i wychowawcy są pedagogami, którzy poddają kontroli badawczej, analizom porównawczym i refleksji teoretycznej sprawy wychowawcze, teoretyzuja na tematy wychowawcze. Są jednak pedagodzy amatorsko traktujący swe powołanie, do jakich zaliczał tę część kadr 
instruktorskich w harcerstwie, która poddaje refleksji swoją aktywność, penetruje środowiskowe przyczyny sukcesów i porażek rozwojowych, kulturalnych i społecznych oraz poszukuje i aktywizuje czynniki mogące „wesprzeć [...] wychowawcze naprostowywanie spaczeń, inicjowanie sytuacji sprzyjających pomyślności we wszechstronnym rozwoju jednostek, grup, społeczności [...]”14, to - „[...] sól intelektualna swych kręgów koleżeńskich"15.

Wychowawcy harcerscy wpisują się w szeroko pojmowaną grupę pedagogów społecznych, która może być lepiej przygotowana do podejmowania działania w tkance społecznej wobec trzech kategorii osób: zagrożonych wyłączeniem, wyłączanych i już wyłączonych (wykluczonych) z życia społecznego. Tak rozumiani instruktorzy orientują działania na opiekę i pomoc, na wychowanie, inkulturację, edukację i animację procesów wspomagających rozwój innego człowieka czy grup społecznych. Na tym też polegała siła skautingu, harcerstwa, że był on od samego początku ruchem inkluzyjnym, a nie ekskluzywnym, elitarnym, zarezerwowanym dla określonej grupy społecznej. Jest w tym zbieżność z oczekiwaniami A. Kamińskiego, by czynić pedagogikę społeczną pedagogiką środowiskową w tym sensie, że potraktujemy harcerstwo jako środowisko ludzkiego życia, które wymaga nie tyle jego instytucjonalizacji, ile nasycania je intencjonalnością wychowawczą i dostrzegania w nim dotychczas sobie nieuświadamianych przez kadry instruktorskie wychowawczych możliwości w zakresie lepszego wspomagania rozwoju osobowości dzieci, młodzieży i dorosłych.

Kamiński jednoznacznie opowiadał się za pedagogiką humanistyczną w harcerstwie, która stoi po stronie wychowywania innych istot $\mathrm{z}$ pełnym poszanowaniem ich godności. $\mathrm{W}$ tym ujęciu pedagog organizuje, reorganizuje i ulepsza środowisko

nie tyle dla ludzi z tego środowiska i nie tyle przez ludzi tego środowiska, lecz nade wszystko wspólnie z ludźmi środowiska, kiedy to wy-

14 A. Kamiński, Studia i szkice pedagogiczne, PWN, Warszawa 1978, s. 6-7.

15 Ibidem, s. 5. 
chowawca jest wśród ludzi jako powiernik, doradca, animator, przodownik i rzecznik ${ }^{16}$.

Wychowawca-pedagog

postrzega wychowanka zawsze dwojako, widząc $\mathrm{w}$ nim nie tylko przedmiot, ale i podmiot procesu wychowawczego. Proces ten widzi we współdziałaniu z jednostką obdarzoną samoświadomością, nawet gdy jednostka ta jest dzieckiem. Dla pedagoga nie do przyjęcia jest podział na manipulujących i manipulowanych, na urabiających i urabianych. Pedagog widzi wychowawcę jako specjalistę działającego wśród ludzi, zjednującego ich dla wartości i motywacji wyższego poziomu17.

\section{Swoistość wychowania pośredniego w harcerstwie}

Siłą harcerstwa jest to, że może ono włączać do życia społecznego i sprzyjać odzyskiwaniu mocy własnej wartości, aspiracji, szans na lepsze życie tych, którzy są pozbawiani właśnie takich nadziei w swoim środowisku rodzinnym (które bywa, że jest środowiskiem zagrożenia społecznego, dysfunkcyjnym), szkolnym, pozaszkolnym czy zawodowym. Harcerstwo zawsze najlepiej sprawdzało się w tym właśnie obszarze społecznego życia, w ratowaniu i wydobywaniu na powierzchnię życia osób wartościowych, a mimo to gdzieś i przez innych marginalizowanych, zaniedbanych, szykanowanych, ale i o zaniżonym poczuciu wartości, niepewnych siebie, o niezaspokojonej potrzebie afiliacji, bezpieczeństwa czy przynależności i samorealizacji, poszukujących społecznie wartościowych celów, pragnących się sprawdzić czy poświęcić innym.

Szczególna wartość harcerstwa wynika z właściwej pracy z kandydatami do wstąpienia w jego szeregi, gdyż po dokonanym przez nich akcie inicjacji trzeba zatroszczyć się o to, aby złożone przyrzeczenie nie było naruszone. W tym też sensie rację miał Baden Powell, kiedy stanowił najważniejsze prawo samowychowawcze dla

16 Ibidem, s. 29.

17 Ibidem. 
wszystkich jego członków, w tym także funkcyjnych - harcerzy i instruktorów: kto raz został harcerzem (a więc kto raz dał słowo, zobowiązał się przy świadkach do czegoś), ten jest nim już na zawsze albo wcale. Zdaniem A. Kamińskiego jakość i siła wpływów wychowawczych „zależy w sposób decydujący od tego, czy w (...) strukturę organizacyjną «wmontowane» są bodźce zachęcające do ulepszeń, do samodoskonalenia w zakresie ukierunkowania i efektywności postępowania wychowawczego)"18. Dlatego tak istotną rolę odgrywają w harcerstwie wszelkie bodźce samowychowania, ale i warunki sprzyjające poprawnej selekcji kadry instruktorskiej oraz procesów samorządnościowe w całym ruchu. Nie unikniemy $\mathrm{w}$ tym procesie pedagogiki pojmowanej jako wiedza, która ma charakter prywatny, osobisty i wynika z gromadzonych przez lata doświadczeń na podłożu własnej praktyki. W skład tak rozumianego systemu poznawczego wychowawców wchodzą ich umiejętności, wzory postrzegania, oczekiwania, oceny oraz strategie osobistego działania pedagogicznego ${ }^{19}$.

Mimo znaczącego rozwoju pedagogiki ogólnej na świecie, naukowych monografii poświęconych kategoriom pojęciowym pedagogiki teoretycznej i praktycznej, instruktorzy harcerscy oporni są na asymilację i aplikację wiedzy naukowej, nadając swoim rozważaniom, refleksjom i większości publikacji potoczny charakter. Ich analizy są ustawicznym powtarzaniem eklektycznego uzasadniania wyjątkowości harcerstwa przez przypisywanie współczesnemu namysłowi nad nim rzekomej wielowymiarowości jego natury. Jak pisze Jakub J. Czarkowski: „Harcerstwo nie jest, ani jedynie organizacją czy instytucją wychowawczą, ani jedynie ruchem społecznym (często bardzo spontanicznym), jest jednak wszystkimi tymi rzeczami po trosze"20. Co ciekawe, autor dokonuje takiej właśnie cha-

18 A. Kamiński, op. cit., s. 77.

${ }^{19}$ J.-L. Patry, Dlaczego nauka o wychowaniu ma tak maty wptyw na wychowanie?, „Edukacja” 1993, nr 4.

${ }^{20}$ J.J. Czarkowski, O metodzie harcerskiej i jej rozwoju, [w:] Na tropach harcerskiej metodyki. 100 lat harcerstwa polskiego, red. Grażyna Miłkowska, Krystyna Stech, Oficyna Wydawnicza Uniwersytetu Zielonogórskiego, Zielona Góra 2011, s. 16. 
rakterystyki natury harcerstwa $\mathrm{w}$ podrozdziale zatytułowanym „U źródeł powstania metody”. Podobnie podeszła do naukowej analizy harcerstwa Krystyna Stech, stwierdzając, że można mówić o polikategorialności jego ujęć, „co wynika z niemożności jednoznacznego określenia istoty tak złożonego i wielowymiarowego fenomenu, jakim jest harcerstwo" 21 . To koncentracja na próbie uchwycenia harcerstwa w całej jego istocie sprawia, że zanika wgląd w to, co stanowi o jego szczególnej cesze, jaką jest właśnie swoistość wychowania pośredniego. Kiedy harcerstwu nadaje się miano - ruchu, systemu, organizacji, związku, stylu życia, gry, wędrowania, a nawet metody wychowania czy/i nauczania, to znika z pola widzenia to, czego doświadczają i co współkonstytuują we wzajemnych relacjach harcerze i ich instruktorzy. Rozprawy na temat tego, czym jest skauting, czy czym jest harcerstwo, nie dają odpowiedzi na pytanie, czym jest skautowe czy harcerskie wychowanie.

Aleksander Kamiński trafnie zidentyfikował fenomen harcerstwa, który został przez kolejne pokolenia zinstrumentalizowany, zredukowany do metody, chociaż nią w swej istocie nie jest.

Skauting angielski jest przede wszystkim grą, kształcącym, lecz zarazem swobodnym, prostym i wesołym spędzaniem czasu. Harcerstwo polskie jest także grą, ale grą, która pragnie bardzo serio traktować harcerski ideał wychowawczy. Można by niejako powiedzieć, że młodzież polska podnosi stawkę skautowej gry²2.

Takie podejście do wychowania sprawia, że koncentrujemy się na instrumentalnym wymiarze harcerskich form aktywności identyfikując w nich elementy owej gry, zabawy, ćwiczeń, usprawniania określonych umiejętności czy sprawności. Interesuje nas wówczas wczasowa funkcja harcerstwa, dla której kluczowy jest właśnie archetyp "gry-zabawy"

która nie jest „zwyczajnym życiem”, lecz bezinteresownie wychodzi poza „proces bezpośredniego zaspokojenia konieczności i żądz, a na-

${ }^{21}$ K. Stech, Spoteczny zasięg metodyki harcerskiej, [w:] Na tropach ..., op. cit., s. 53.

22 A. Kamiński, Nauczanie i wychowanie metodą harcerską, Nasza Księgarnia, Warszawa 1948, s. 24. 
wet ów proces przerywa - „służy kulturze, a nawet więcej jeszcze: sama staje się kulturą". Zabawa-gra "łączy i dzieli” Przykuwa. Urzeka: czyli oczarowuje. [...] Nadaje człowiekowi podmiotowość, o ile ten panuje nad nią i przestrzega jej reguł. Toteż im w ruchu harcerskim silniejsza jest funkcja wczasowa, tym pełniej realizowane są inne funkcje (np. wychowawcza, samowychowawcza, przygotowawcza do zorganizowanego życia społecznego $)^{23}$.

Wynika z tego, że wychowanie ma miejsce w ramach inaczej i jakoś realizowanej funkcji wychowawczej, ale już nie wczasowej, samowychowawczej czy preparacyjnej.

Stanisław Czopowicz proponuje spojrzenie na harcerstwo w wymiarze modelu heurystycznego jako ruchu społecznego, który jest zorientowany na wartości i zmierza

do ich urzeczywistnienia przez realizację własnego programu pracy według harcerskiej metody wychowawczej, pod przewodnictwem instruktorów harcerskich, we własnej organizacji służącej i podporządkowanej ruchowi, wartościom, programowi, metodzie wychowawczej i formacji instruktorów. Trzeba zatem zobaczyć nie konstrukt teoretyczny, lecz dynamiczną rzeczywistość praktykowaną, w której da się wyodrębnić jej podstawowe elementy składowe: 1 . Ruch społeczny dzieci, młodzieży i dorosłych, 2. Ideę wyznaczającą cel, wartości, zasady i styl życia, 3. Instruktorów - kierowników, przywódców i wychowawców, 4. Organizację i struktury organizacyjne, 5. Program pracy oraz 6. Metodę wychowawczą ${ }^{24}$.

Autor dodaje, że te elementy wzajemnie się przenikają, dopełniają, warunkują, tworząc niezależną całość, toteż ich wyróżnienie ma jedynie teoretyczny charakter. Także w tym ujęciu instruktora, a zarazem naukowca, teologa, który - jak pisze - posłużył się metodą teologii pastoralnej z wykorzystaniem metody analizy (indukcji) danych dyscyplin humanistycznych (historii, socjologii, pedagogiki

23 S. Czopowicz, Szczera wola i zniewolenie. Harcerstwo w Polsce 1945-1980. Zarys problematyki ideowej $i$ wychowawczej, Niezależne Wydawnictwo Harcerskie, Warszawa 2010, s. 15.

${ }^{24}$ Ibidem, s. 13. 
społecznej) widać, jak trudno jest dostrzec, że kiedy wychowanie jest fenomenem dopełniającym czyjeś i jakieś działanie, co w tym przypadku zostaje określone mianem "metody wychowawczej”, to poprzestajemy na jego behawioralnym wymiarze wpisującym się $\mathrm{W}$ racjonalność instrumentalną. Na domiar tego S. Czopowicz przyjmuje z pedagogiki społecznej jej instytucjonalny punkt widzenia, by analizować dane historyczne i socjologiczne o harcerstwie wskazujące na to, jak czynią one

harcerstwo instytucją wychowawczą bądź stają temu na przeszkodzie. Ten rodzaj pedagogiki nie koncentruje się na stosunku wychowawcawychowanek (lub grupa wychowanków), lecz na procesie wychowawczym i obserwuje w każdym kręgu środowiskowym potencjalne środowisko wychowawcze (lub antywychowawcze), zaś krzyżowanie się wpływów jednostki i środowiska postrzega jako czynnik dynamizujący pożądane (lub niepożądane) wychowawczo kształtowanie postaw i zachowań ${ }^{25}$.

Każdy badacz związku młodzieży powinien potraktować swoistość procesu wychowawczego jako składnik narodowej struktury wychowawczej. Z tego zapewne powodu większość badaczy traktuje harcerstwo jako środowisko wychowawcze, którego suwerenność jest ograniczana włączaniem go przez rządzących w ramy instytucji czy ośrodków wychowania pozaszkolnego i pozarodzinnego, niezależnie od tego, że nie ma tu miejsca całkowity brak wzajemnych między nimi interakcji. Analiza dyskusji nad wprowadzaniem zmian prawnych, które poprzedzają wystąpienia dotyczące projektów poprawy statutu czy ustaw, w dokumentacje posiedzeń różnych organów władz harcerskich, ich podstawowych jednostek itp. pozwala na odczytanie, jak życie związkowe narzucało, utrwalało czy blokowało zaistnienie nowych rozwiązań, reorientację ideową, organizacyjną i metodyczną.

Zasługą pedagogów społecznych było uporczywe dążenie do ujęcia $\mathrm{w}$ ramy świadomych procesów wychowawczych możliwie pełnego

25 S. Czopowicz, op. cit., s. 27-28. 
życia człowieka oraz do traktowania jako funkcji wychowawczych całego bogactwa form działalności społecznej ${ }^{26}$.

Z powyższych źródeł można odczytać, co wzbudzało w środowisku instruktorskim, ale i pozazwiązkowym zastrzeżenia, wątpliwości, pragnienie korekt czy konieczność formalnej legalizacji pożądanych zmian i w jakim stopniu były one gruntowne czy może powierzchowne, pozorne. Nie jest bowiem bez znaczenia, co wprowadzano do fundamentalnych dla harcerstwa dokumentów statutowych, organizacyjnych, gdyż te były przekładane na język metodyki wychowania i pragmatyki awansowej kadr instruktorskich.

Kamiński jednoznacznie wskazywał na powinność przyjęcia w badaniach pedagogicznych punktu widzenia nie tylko historii pedagogiki, ale przede wszystkim pedagogiki społecznej, dla której najistotniejsze jest skoncentrowanie się nie

na stosunku wychowawczym pojmowanym jako swoisty dialog: wychowawca - wychowanek lub wychowawca-grupa wychowanków, lecz na procesie wychowawczym, dostrzegającym w każdym kręgu środowiskowym potencjalne środowisko wychowawcze, a w krzyżowaniu się wzajemnych wpływów jednostki i środowiska - czynnik dynamizujący pożądane wychowawczo kształtowanie zachowań ludzkich $\mathrm{w}$ toku meliorowania przez zainteresowanych ich środowiska życia - rodzinnego, koleżeńskiego, sąsiedzkiego etc. ${ }^{27}$.

Było to częściowym odejściem od prymarnego pojmowania wychowania skautowego/harcerskiego jako wychowania pośredniego na rzecz dominacji wpływów środowiskowych, w tym spontanicznych, które instruktorzy mogliby „uczynić intencjonalnie ukierunkowanymi, a więc włączonymi w procesy wychowawcze"28. Punkt widzenia łódzkiego pedagoga społecznego pozwala na wyraźne

${ }^{26}$ A. Kamiński, Prehistoria polskich związków młodzieży, PWN, Warszawa 1959, s. 26.

27 A. Kamiński, Analiza teoretyczna polskich związków młodzieży do połowy XIX wieku, PWN, Warszawa 1971, s. 11.

28 Ibidem, s. 25. 
lokowanie jego preferencji ontologicznych i epistemologicznych w pojmowaniu wychowania i badaniu jego występowania w związku młodzieży jako charakterystycznych dla funkcjonalizmu socjologicznego. On sam podjął się naukowej analizy pojęcia wychowanie $\mathrm{w}$ rozprawach wydawanych po II wojnie światowej. W okresie PRL-u przeważały neobehawioralnej definicje tego pojęcia $\mathrm{w}$ ramach pedagogiki podporządkowanej filozoficznie przez marksizmleninizm, to jednak A. Kamiński dystansował się wobec nich uzasadnieniem wykraczającym poza powyższe uwikłania znaczeń, pisząc, iż „musimy skupić się [...] na pedagogice społecznej i na tym, jak dyscyplina ta pojmuje wychowanie" 29.

Bardzo wyraźne odcięcie się od ideologii na rzecz postrzegania procesu wychowania w jego środowiskowych i osobowościowych uwarunkowaniach jest zgodne z tożsamością pedagogiki społecznej i etyką naukową. Akcentując holistyczny wymiar rozwoju człowieka jako istoty bio-socjo-kulturalnej, nawiązywał Kamiński do filozofii człowieka filozofa wychowania Sergiusza Hessena ${ }^{30}$. Zbieżność poglądów na istotę wychowania w pedagogice społecznej łódzkiego pedagoga dopełnia jego fascynacja filozofią par excellence humanistyczną i personalistyczną tak bliskiego mu Sergiusza Hessena, który był jego przełożonym na Uniwersytecie Łódzkim, a jego teksty ze względu na neokantowski idealizm i antykomunizm objęte były cenzurą. Jak pisał A. Kamiński:

$\mathrm{w}$ pracach z zakresu pedagogiki społecznej można dostrzec dwa odmienne jej ujmowania: jedno - jako swoisty kierunek pedagogiczny, drugie - jako odrębną dyscyplinę. Jako jeden z kierunków pedagogicznych jest to pedagogika specyficznie traktująca proces wychowawczy ${ }^{31}$.

${ }^{29}$ A. Kamiński, Podstawowe pojęcia pedagogiki społecznej w pracy socjalnej, IW CRZZ, Warszawa 1976, s. 7.

30 Szerzej: B. Śliwerski, Wkład pedagogii Aleksandra Kamińskiego do współczesnej teorii wychowania humanistycznego, [w:] Bogactwo życia i twórczości Aleksandra Kamińskiego, red. I. Lepalczyk i W. Ciczkowski, Wydawnictwo Adam Marszałek, Torun 1999, s. 94-106.

${ }^{31}$ A. Kamiński, Pedagogika społeczna w dorobku nauk pedagogicznych w Polsce Ludowej, „Człowiek w Pracy i Osiedlu” 1978 Nr 1, s. 61. 
Istotę tego procesu ujmował zatem nie tylko z perspektywy pedagogiki społecznej jako odrębnej dyscypliny nauk o wychowaniu, ale właśnie w kontekście wiedzy ogólnopedagogicznej32. Brakuje we współczesnych pracach z pedagogiki harcerskiej koniecznej modyfikacji teorii socjalizacji także w tym ruchu. Czeka nas zatem podjęcie badań, w których uwzględnionoby wieloaspektowy i interdyscyplinarny charakter pośredniego wychowania.

\section{Bibliografia}

Czarkowski J.J., O metodzie harcerskiej i jej rozwoju, [w:] Na tropach harcerskiej metodyki. 100 lat harcerstwa polskiego, red. Grażyna Miłkowska, Krystyna Stech, Oficyna Wydawnicza Uniwersytetu Zielonogórskiego, Zielona Góra 2011.

Czopowicz S., Szczera wola i zniewolenie. Harcerstwo w Polsce 1945-1980. Zarys problematyki ideowej i wychowawczej, Niezależne Wydawnictwo Harcerskie, Warszawa 2010.

Glass H., Gawędy z drużynowym. Zbiór rad i wskazówek dla instruktorów harcerskich, Warszawa 1923, s. 48.

Hejnicka-Bezwińska T., Pedagogika ogólna, WAiP, Warszawa 2008.

Kamiński A., Analiza teoretyczna polskich zwiazków młodzieży do połowy XIX wieku, PWN, Warszawa 1971.

Kamiński A., Nauczanie i wychowanie metodą harcerską, Nasza Księgarnia, Warszawa 1948.

Kamiński A., Pedagogika społeczna w dorobku nauk pedagogicznych w Polsce Ludowej, "Człowiek w Pracy i Osiedlu" 1978, Nr 1.

Kamiński A., Podstawowe pojęcia pedagogiki społecznej w pracy socjalnej, IW CRZZ, Warszawa 1976.

Kamiński A., Prehistoria polskich zwiazków młodzieży, PWN, Warszawa 1959.

Kamiński A., Przedmowa, [w:] Skauting i Harcerstwo. Wybór pism charakteryzujących ruch mtodzieży $i$ system wychowawczy, oprac. Aleksander Kamiński, Oficyna Wydawnicza „Impuls” Kraków 2015, s. 5 (Reprint maszynopisu autorskiego z 1946 roku).

Kamiński A., Studia i szkice pedagogiczne, PWN, Warszawa 1978.

Massalski A., Przewodniczacy Zwiazku Harcerstwa Polskiego, [w:] Dorobek pedagogiki harcerskiej. Materiały z konferencji naukowej zorganizowanej w 50. rocznice powstania

32 Szerzej: B. Śliwerski, Wkład pedagogii Aleksandra Kamińskiego do wspótczesnej teorii wychowania humanistycznego, [w:] Bogactwo życia i twórczości..., op. cit., s. 94-106. 
„Nieprzetartego Szlaku”, Wyższa Szkoła Filozoficzno-Pedagogiczna „Ignatianum", Komisja Historyczna Krakowskiej Chorągwi ZHP, Kraków 2008.

Patry J.-L., Dlaczego nauka o wychowaniu ma tak maty wptyw na wychowanie?, „Edukacja" 1993, nr 4.

Schütterly K.B., Pedagogika ZHP - mity a rzeczywistość, [w:] Dorobek pedagogiki harcerskiej. Materiaty $z$ konferencji naukowej zorganizowanej w 50. rocznice powstania „Nieprzetartego Szlaku”, Wyższa Szkoła Filozoficzno-Pedagogiczna „Ignatianum", Komisja Historyczna Krakowskiej Chorągwi ZHP, Kraków 2008.

Sedlaczek S., Podstawy etyczne skautingu Baden-Powellowskiego, Oficyna Wydawnicza "Impuls”, Kraków 2015 (Reprint wydania z 1928 roku).

Sosnowski J., O wychowaniu w ogóle i wychowaniu harcerskim, Oficyna Wydawnicza „Impuls”, Kraków 2016 (Reprint z nieopubl. wydruku z 1946 roku).

Stech K., Spoteczny zasieg metodyki harcerskiej, [w:] Na tropach harcerskiej metodyki. 100 lat harcerstwa polskiego, red. Grażyna Miłkowska, Krystyna Stech, Oficyna Wydawnicza Uniwersytetu Zielonogórskiego, Zielona Góra 2011.

Strumiłło T., Harcerstwo a szkoła, [bez miejsca wydania i daty/nadbitka] W. Błażejewski, Bibliografia Harcerska 1911-1960, Warszawa 1980, sugeruje rok wydania 1921.

Śliwerski B., Wkład pedagogii Aleksandra Kamińskiego do wspótczesnej teorii wychowania humanistycznego, [w:] Bogactwo życia $i$ twórczości Aleksandra Kamińskiego, pod red. I. Lepalczyk i W. Ciczkowskiego, Wydawnictwo Adam Marszałek, Torun 1999.

Tworkowska J., Równajmy krok. O wspótpracy z Ruchem Harcerskim Nauczycielstwa i Rodziców, Oficyna Wydawnicza „Impuls”, Kraków 2016 (reprint wydania z 1931 r.).

Znaniecki F., Socjologia Wychowania, tom I. Wychowujące społeczeństwo, Książnica Atlas Towarzystwo Nauczycieli Szkół Wyższszych, Warszawa 1928. 